\title{
THE DEVELOPMENT OF LODZ IN VIEW OF ITS CANDIDATURE TO HOST THE INTERNATIONAL SPECIALIZED EXPO
}

\author{
ROZWÓJ LODZI W PERSPEKTYWIE KANDYDATURY \\ NA ORGANIZACJĘ MIĘDZYNARODOWEJ WYSTAWY EXPO
}

DOI: $10.25167 / \mathrm{sm} 2017.025 .10 \quad$ s. $163-175$

\begin{abstract}
The article opens the discussion about the strategic directions of the development of Lodz in the context of the application to organize the Expo 2022 put forward by the Polish government. The aim of the study is to assess the influence of the International Exposition on urban policy. The methodology rests on a careful analysis of the current activities carried out by the public authorities, both at the ministerial and city council levels. The juxtaposition of the adopted strategy in Lodz with the practical aspects of organizing the previous exhibitions forms an important part of the analysis. The study shows that the event focused on revitalisation may complement projects which are being introduced today. In the context of the dynamics of post-industrial city development, the Expo 2022 in Lodz may become an open platform for experience exchange and redefine the image of the analyzed area.
\end{abstract}

KEY WORDS: Lodz, revitalisation, Expo

ABSTRAKT: Artykuł otwiera dyskusję nad strategicznymi kierunkami rozwoju Łodzi w kontekście złożonej przez Rząd Polski kandydatury na organizację Expo Łódź 2022. Celem opracowania jest ocena wpływu Międzynarodowej Wystawy na prowadzoną politykę miejską. Metodologię badań oparto na wnikliwej analizie aktualnych działań władz publicznych, zarówno na poziomie decyzji ministerialnych, jak i samorządowych. Ważnym aspektem analizy jest zestawienie przyjętych założeń z praktyką organizacji minionych wystaw. Przeprowadzone badania wykazały, iż specyfika wydarzenia, koncentrującego działania wokół zagadnienia rewitalizacji, może się stać doskonałym uzupełnieniem aktualnie prowadzonych projektów. W obliczu nowej dynamiki rozwoju miast postindustrialnych Expo Łódź 2022 może się stać otwartą platformą wymiany doświadczeń, definiującą nowy obraz badanego obszaru.

SŁOWA KLUCZOWE: Łódź, rewitalizacja, Expo

* Politechnika Łódzka, Wydział Budownictwa, Architektury i Inżynierii Środowiska, Instytut Architektury, al. Politechniki 6, 90-924 Łódź, e-mail: monikacysek@tlen.pl 


\section{Introduction}

The article focused on the strategic directions of the development of Lodz in the context of Poland's bid to organize Expo 2022. This cyclical event is one of the most representive of thematic festivals touching the key problems of the modern world. The objective of the study was to assess the influence of the International Exposition on urban policy. To that end, strategies formulated by urban renewal programs, individual yet significant public investments and legislative directives on urban renewal were examined. The methodology rested on a careful analysis of the current activities carried out by the public authorities, both at the ministerial and city council levels. Secondly, the possibility of complementing these activities by a major cultural event such as the Expo was considered. Finally, the strategy adopted in Lodz was contrasted with issues and solutions which had appeared during previous Expositions, so that final decisions concerning Expo 2022 be taken with the full awareness of dangers and possibilities that hosting such an event offers. Whether or not the exhibition strenghtens the redevelopment of Lodz depends on project solutions proposed and accepted today. It is therefore extremely important to ensure the high quality of projects as they are forming a new vision of the city in front of our eyes.

\section{Local conditions and Expo project impact possibilities}

The once prosperous Lodz with its flourishing textile industry has been in decline since the crisis in the 1970s. Currently, it is one of the most rapidly depopulating cities in Poland (Polish Central Statistical Office, 2015-2035 prognosis). The net migration rate is -1.5 thousand people a year (the City of Lodz Urban Development Strategy 2020+). The negative economic, social and urban phenomena are escalating, especially in the city center structure. According to a study carried out by the Social Renewal Strategy, $23 \%$ of Lodz inhabitants describe the living conditions in the city center as bad (the National Strategy of Urban Renewal 2015, 17). It is therefore clear that the development strategy needs to be redefined to include exploiting and building upon the industrial inheritance of the city.

Many of the projects in Lodz were planned independently from the bid to host Expo 2022. The adaptation of the EC1 heat power station complex, the multimodal train station, the New City Center of Lodz or the currently introduced Area Renewal Project all serve as examples. These investments were briefly described below to asses how well they cohere with the strategy of the Lodz Expo project. An analysis of the experiences of former host countries showed that the candidature itself can exert a significant influence on investments that have already been accepted. The mayor of Turin responsible for urban issues said: "the choice of Turin to host the Winter Games reassured investors and gave credibility to the renewal of the city" (Viano 2006, 75). Similarily, in Hannover, two additional S-train rails which connected the area of the event with the city center 


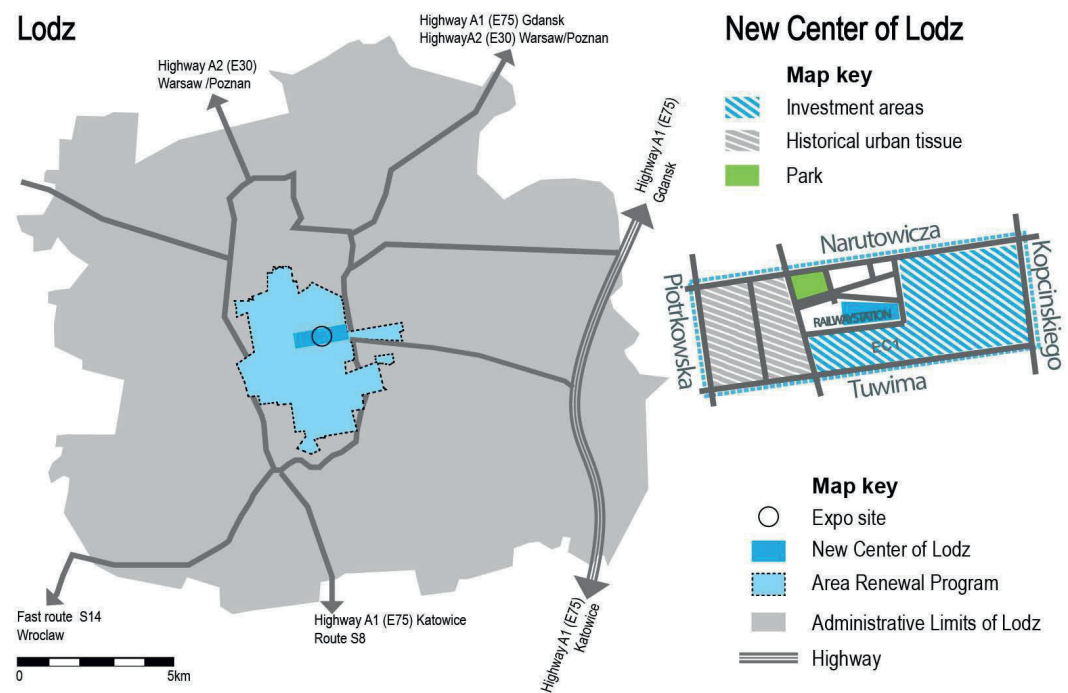

Figure 1. Lodz and the New Center of Lodz

Source: Monika Maria Cysek-Pawlak, 2017

and airport would have been built irrespective of whether the city was granted the right to organize the event or not. However, it would have definitely happened much later (Luginsland 1994). A similar position is taken by the local authorities in Lodz who draw attention to the approved plan of building a city tunnel or completing the city ring route by opening the $S 14$ road.

\section{Current strategy in Lodz and key its projects}

Thanks to its scale and functional variety, the New Center of Lodz (NCL) may be seen as a symbol of structural changes that Lodz is undergoing. An area spanning over 100 ha in the heart of the city center will be restructurized to raise the standard of living and make it attractive for visitors from out of town. A modern quarter connecting businness, trade, culture and transportation will undergo a deep urban transformation. The project started 10 years ago when Rob Krier, one of the main representatives of New Classicism, put forward an initial concept of the area. The decisions made in the Local Urban Plan, already in force today, reflected the basic tenets of Krier's vision. According to the plan, the multimodal station was located strategically so that the area separated by ul. Narutowicza, ul. Piotrkowska, ul. Tuwima and ul. Kopcińskiego could become a catalyst dynamizing the entire city. The quarter once divided by a train station was supposed to be 'sewn' back together. However, in practice, moving the train station underground made room for a wide four-lane street. A highway of this kind posed no smaller spatial obstacle than a railway station. An analysis of the scale of road 
investment in the NCL ( $12.5 \mathrm{~km}$ including: $3 \mathrm{~km}$ of new, $3 \mathrm{~km}$ of rebuilt and $3 \mathrm{~km}$ of modernized roads) showed that the adopted urban transport strategy appears debatable. In comparison, the area analysed comprises less than $2 \mathrm{~km}$ of new tram railway track. The balance of public transport development is of course improved by the new multimodal station which also constitutes the heart of the NCL operation. The city is still searching for businessmen willing to purchase building plots in the central area dubbed the "Special Culture Sphere" (Specjalna Strefa Kultury) but this key element of the urban development strategy should attract new developers to the city, including those who until now have invested in Warsaw. The areas north and west of the new station (investments by the Skanska and Budomal companies) are slowly becoming commercialized. The interest in the quarter would definitely be greater had the project of High-Speed Railway (KDP) not been postponed (2030 prospect). It was thanks to the Y line connecting Lodz with Warsaw, Poznan and Wroclaw that the NCL area had a chance to compete against expensive real estate in the capital. The city tunnel passing under the heart of the city center is the only project of the initial plan that is still to be introduced. However, the planned tunnel which connects the Lodz Fabryczna station located in the NCL with the Lodz Kaliska station located in the western part of the city is compatible with conventional rail only. If the KDP project is to be realised, a separate tunnel will have to be built. However, in spite of this, the concept of a multimodal station remains a valuable strategic proposal.

In the context of Expo 2022, one may wonder how the full potential of the exhibition may be better developed. A multimodal interchange hub serving 200 thousand passangers per day is an excellent answer to the transportation needs of the exhibi-

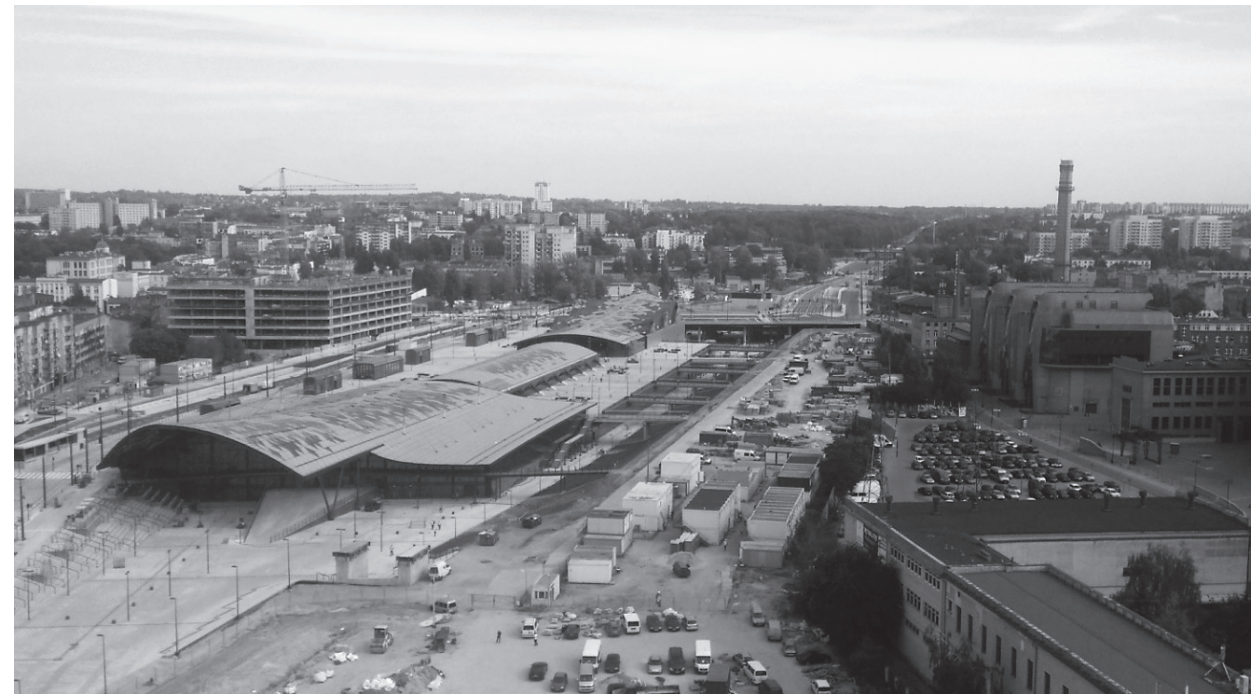

Figure 2. The NCL, the Lodz Fabryczna station and part of the EC1 complex perspective Source: Monika Maria Cysek-Pawlak, 2016 
tion. However, the question remains, how such an important area should be managed on a regular basis. A carefully planned and executed Expo event will attract investors to the area as the space above the station as well as building plots around it remain empty. Refining the surrounding spaces and connecting the entrances to the station at the -8 level to the surrounding urban tissue is another important element of this strategy.

Given the industrial inheritance of the city, the renewal of the former EC1 heat power station and adapting it to cultural and artistic purposes is key to preserving the city's character (Wiśniewski 2010). The power station is one of the most important elements of the genius loci of the area. It is an early 19th century complex composed of three basic parts: the eastern, western and - so far never revitalized - south-eastern part. Reviving the historical character of the buildings posed a challenge for the authors of the project and, of course, not all the original structures could be adapted to their new functions (Cysek-Pawlak 2016). Some of today's buildings, especially in the western sector of the EC1 complex, are a reconstruction of the former layout. The eastern complex constitutes an interesting dialogue between modern architecture and historical buildings. The conversion works have to a large extent been finished; however, it has been a decade since the beginning of the operation, and the complex is not fully operational yet. The entire western sector and parts of the building in the east are still unequipped. The delay stems from the procedural intricacies of public investments and, above all, from the difficulties in defining the entire program of the complex. The Science and Technology Center is to be located in the area designed by Mirosław Wiśniewski. An interactive exposition will lead guests along three thematic paths: "Converting energy", "The development of knowledge and civilization" and "The Micro- and Macroworlds". The narration of the exhibition reflects the history of the area by showcasing antique machines in the original interiors. In the eastern part designed by Home of Houses, an architectural company from Poznan, conference areas are already fully operating, hosting various cultural and business events. Moreover, the biggest planetarium in Poland opened there last year. However, the workshop and recording area still remains unused. The latest project suggested that the National Center of Film Art should be located there. Lodz's candidacy has the potential to accelerate the implementation of the project and its strategies. It is especially promising as the south-eastern part of the EC1 complex has yet to undergo renovation works.

A project of a slightly different character, albeit also related to the historical inheritance of the city, is the Area Renewal program. A part of this pilot project is being realized in the NCL area and in its immediate surroundings, including the blocks on ul. Piotrkowska. The initiative aims to cover the entire culturally invaluable Historical Urban Core (the National Strategy of Urban Renewal). The project includes comprehensive renewal undertakings such as activities in the public sphere, living and social sector. The Area Renewal Project, as a public program funded partly by the European Union, has a lot to offer to the poorest inhabitants by encouraging economic activity, fostering education, or providing communal apartments. If the project strategy is integrated 
with the commercial activities of Expo 2022, it may help dynamize local economy even more. Thematically related to the ideas of the Area Renewal Program, the exhibition presents a perfect excuse to broaden the municipal project. It will provide investments which have not been executed because of, for instance, procedural complications. By complementing public activities, Expo 2022 will become a natural catalyst for private investment in Lodz.

\section{Expo Lodz 2022: vision of urban development}

Lodz has been tackling with the degrading processes for years. "Going back to our origins is the solution. Supporting creative industries awakens the memories of the artistic roots of the city. We need to revisit variety, which today has economic, rather than cultural, character. We have to return to the city center" (Kulesza 2016, p.172). The words of the City Hall representative responsible for the Lodz Expo 2022 project succinctly summarize the foundation of the project. They also bring up the concept of the 'Creative City' (Landry 2013), in which innovation lies not only in creating new things but also in appreciating the innovations from the past. It is the historical potential that will allow Lodz to build its future and the exhibition corresponds with the city's background.

The advertising slogan of the event: "City Re:Invented" is a reference to urban city renewal. The idea of organizing Expo in Poland arose in 2013 when Donald Tusk, the then prime minister, announced the need to support the renewal of degraded post-industrial urban structures. The exhibition thus became a way to strenghten the activities and popularize the topic. It was also then that the funds necessary to realize the Area Renewal program appeared. It was a key moment which proved that the problems of post-industrial cities had become an important axis of the urban policy. This, in turn, translated into the following policies: the Urban Renewal Act, National Urban Policy and the National Strategy of Urban Renewal. The government's support of the city's candidature, therefore, is not only a way of promoting the country abroad but also of supporting the accepted development strategies of Polish cities. As the analysis of previous candidatures proves, with the exception of Hannover (Luginsland 1994), the support of the central government is extremely important in assessing individual candidatures. The right to organize the exhibition is granted by the International Exhibitions Bureau (BIE), which currently has 169 member countries.

Lodz is applying for the International Specialized Expo, an event organized every four years in-between larger events of the World Exposition. The difference between the two undertakings refers to the scale, range and organization of the pavilions. The so-called small Expo is thematically focused on a single issue. In the case of Lodz, it is the issue of revitalization. Individual countries, apart from the organizer, do not have separate pavilions and present their heritage in common exhibition areas. The event site covers around 25ha, which, given its location in the heart of the city center, poses 
a challenge to the designers. Locating the Expo in the NCL will make the area more attractive and facilitate its urbanization. However, the inhabitants will have to put up with the temporary closure of the central quarters. As the experience of previous undertakings of the kind shows, fencing the event area for its duration, that is three months, is highly advisable. However, the Expo in Lodz is not limited to the exhibition. A large number of additional events will also take place. The immediate vicinity of ul. Piotrkowska makes it easy for guests to visit. This awakened curiosity will undoubtedly benefit the local economy which today is in dire need of new stimuli for development. The Secretary General of BIE stresses that "participation in an Expo offers opportunities for economic cooperation and provides an ideal framework to promote local identity" (Loscertales 2010).

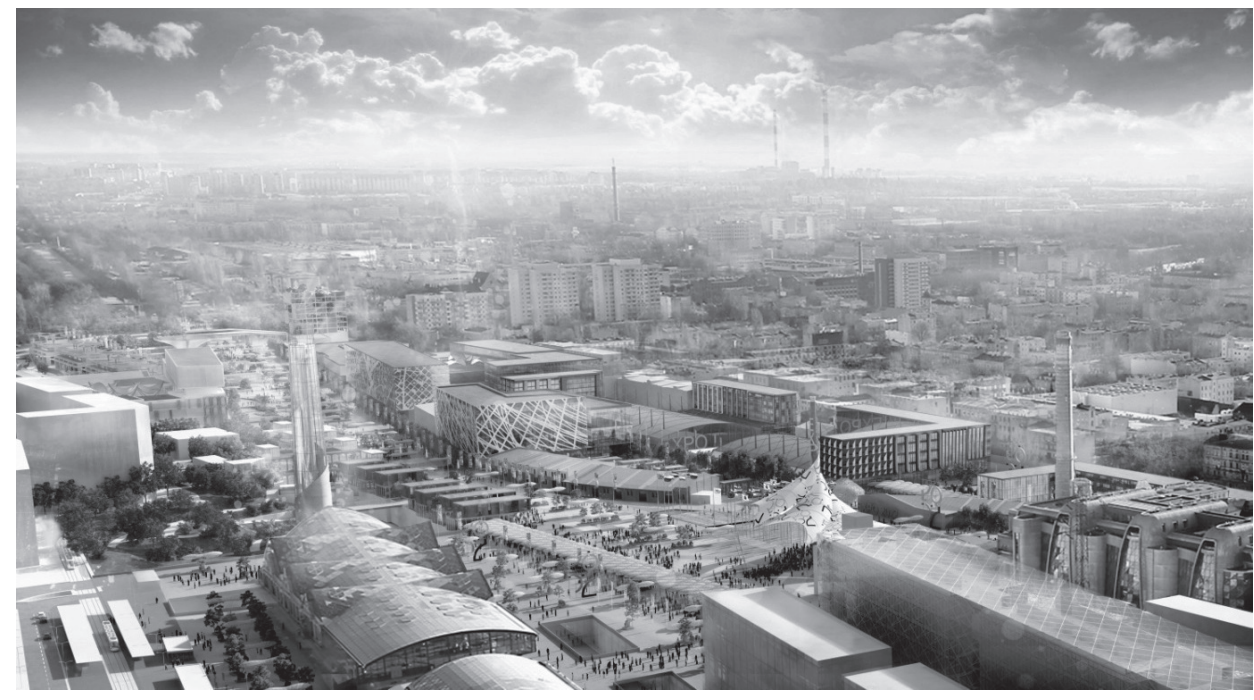

Figure 3. Exhibition area management concept. A train station perspective. The Expo 2022 Feasibility Study materials

Source: The Ministry of Development and the City Council of Lodz, 2016

Commissioned by the Deloitte advisory consortium, the Sud Architekt Polska company planned the spatial management of the exhibition. The urbanists paid special attention to the quality of the designed public spaces. It is the public spaces with buildings that, after the exhibition, become apartments, offices as well as public and private service buildings that constitute the lasting added value. The authors of the project stress that about 80 per cent of buildings will be reused after the exhibition (Magnuszewska 2016). The long-term improvement of the urban tissue is key. Drawing on the experiences from the International Exposition such as the Expo in Saragossa, it is important to make sure that the exhibition sites do not become a desolate quarter unsuitable for everyday use (Delizee 2000). 
According to the project strategy, some of the constructions will be moved after the exhibition. They will serve as sports halls or cultural buildings in their new location. Only buildings which correspond with the target functional structure of the city as described in the Local Urban Plan will remain in the strategic area of the exhibition. This does not, of course, eliminate carrying superstructure or extensions works on the basic exhibition buildings. However, the projects prepared for the event should include the possibility of converting the buildings to serve other functions. That is why creating a detailed plan of the undertaking without losing sight of its different stages is vital. In this context, a cooperation with the future property manager already on the stage of design appears necessary. Eventually, the area should become a functionally varied quarter adapted to the needs of its inhabitants. As Vincente Gonzales Loscertales noticed: "The BIE attaches high importance to the integration of the Expo site into the city and to the need of managing the plan for its reutilization" (Monclús Fraga 2006, 1). Location in the immediate vicinity of the train station will not only be an asset during the exhibition, but also, which is even more critical, will be advantageous to the process of commercialization of the Expo area after the event. Another element which diversifies the structure of the analyzed area is the EC1 complex. The post-industrial complex is contained within the Expo 2022 site and should be treated as the symbol of the event. Including the former heat power station will help make sure that the full potential of the area is exhausted. Moreover, the strategy of preserving and renovating the remainder of historical buildings in the area was adopted. This directive lead to initiating the EC1 south-eastern project and works on other characteristic buildings, including the Heinz factory complex. Apart from elements typical of Lodz post-industrial landscape, apartment buildings in the area will also be renovated and rebuilt. In particular, the plan refers to the dilapidated tenement houses on ul. Tuwima. Activities which are part of the Area Renewal project complement the program. As mentioned above, the urban project aims to take action in the city center, which includes the areas adjacent to the exhibition. Integrated projects will prove mutually beneficial both for the city inhabitants and the Expo guests. On the one hand, high-quality public spaces in the area of the event are designed to meet the needs of local inhabitants of the agglomeration. On the other hand, however, city center renewal will facilitate the free flow of ideas and guests out of the borders of the exhibition.

The list of investments accompanying the Expo also depends on their usefulness to inhabitants after the end of the festival. A railway rolling stock or an additional railway connection in the Lodz agglomeration may serve as examples (Kulesza 2016). At the same time, the organizers have to secure comfortable transportation for visitors. Such exhibitions are visited by a few million people, including not only diplomats and tourists from abroad but most importantly the citizens of the host country. This tendency is clearly visible after the previous events of the kind, especially the specialized exhibition in 2010. The Shanghai exhibition was mostly attended by the Chinese. It is worth stressing that the city has become the main internal migration target (Zhuo 2010). The 2010 event has permanently strengthened the bonds between Shanghai and other 


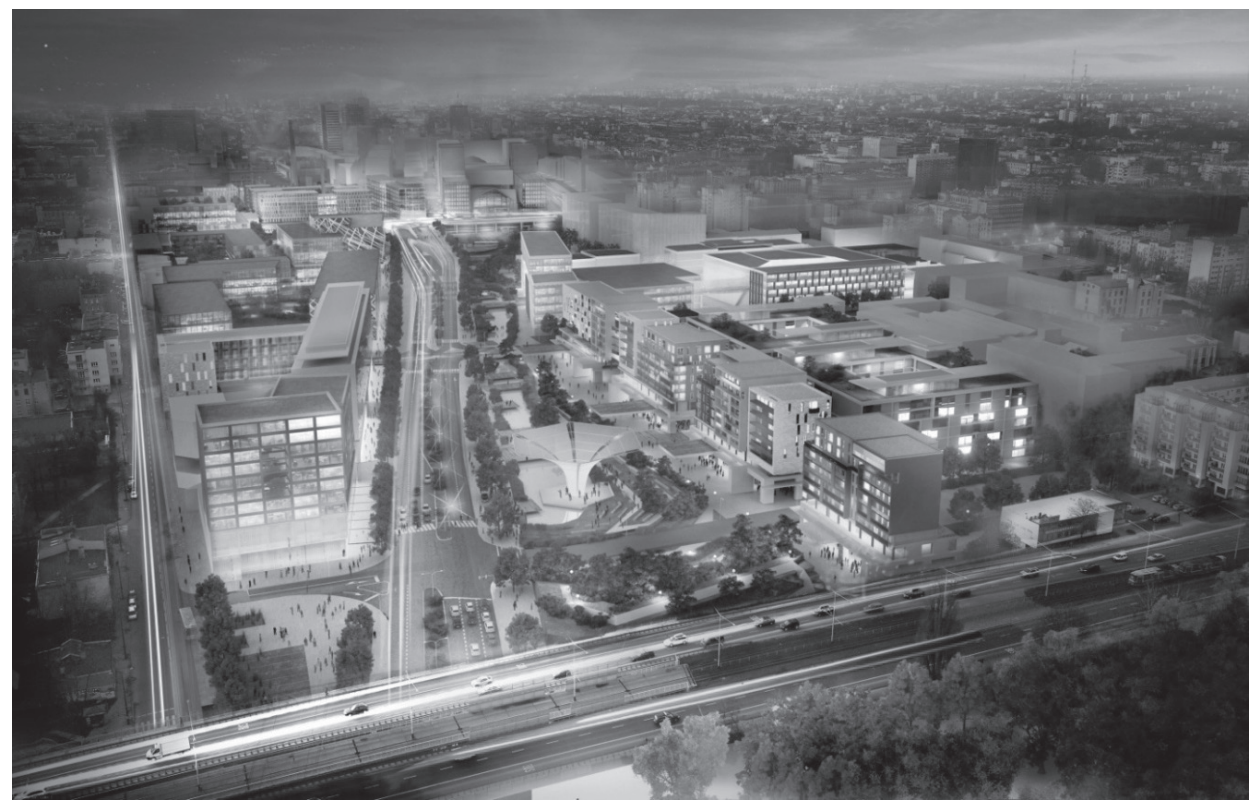

Figure 4. Future Expo area - composition axis perspective. The Expo 2022 feasibility study materials Source: The Ministry of Development and the City Council of Lodz, 2016

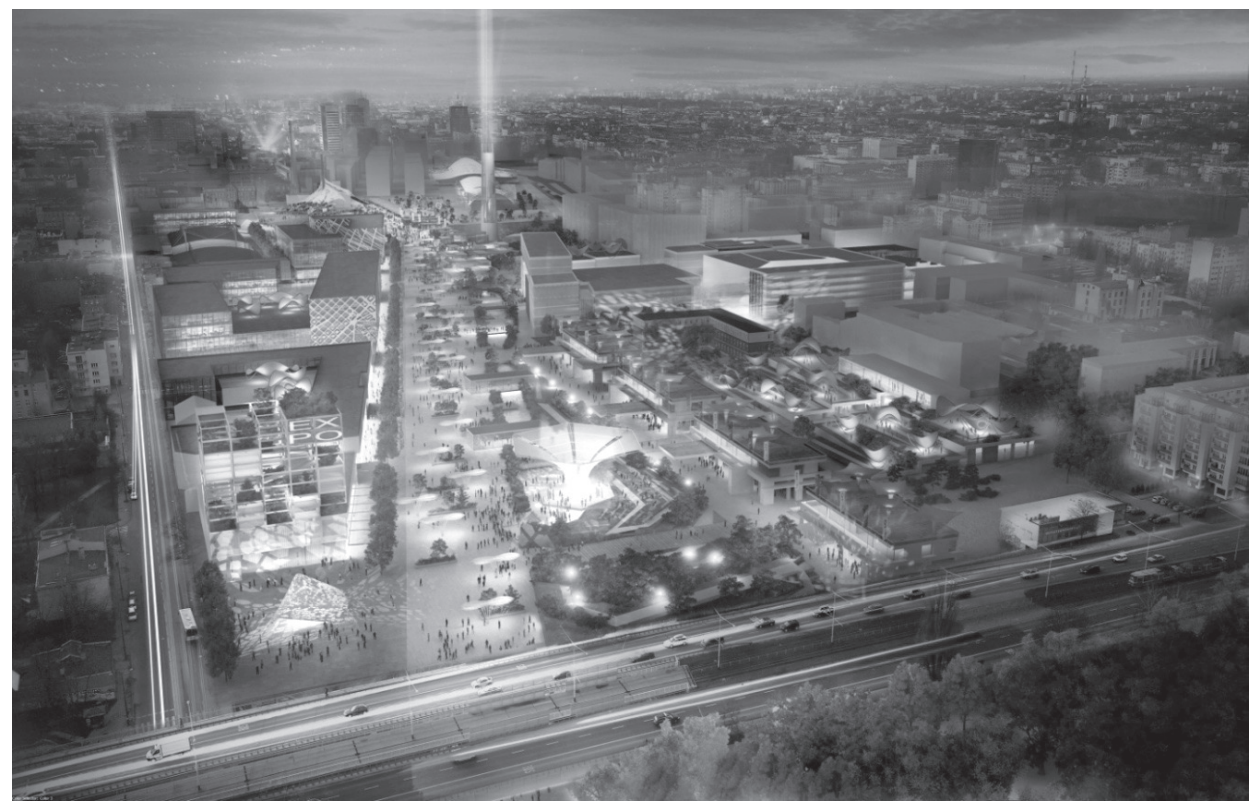

Figure 5. Post-Expo area - composition axis perspective. The Expo 2022 feasibility study materials Source: The Ministry of Development and the City Council of Lodz, 2016 
regions. Moreover, thanks to the event, new standards of public dialogue and internal communication between administrative units which participated in the project were developed. A common goal facilitated completing the investment and contributed to raising the knowledge about the region: "Shanghai 2010 has effectively demonstrated how powerful the educational capabilities of an Expo can be" (Loscertales 2011, 1). The promotional activities proposed by the City Hall may make Lodz equally successful. However, they should be intensified. For the time being, undertakings and projects such as conferences, workshops and promotional movies complement the public debate concerning the broadly defined issue of revitalization well.

\section{A look in retrospect - theory and practice}

The aim of this chapter is to identify possible problems and expected benefits based on the experiences of the previous events. Many of the ideas and strategies of Expo 2022 in Lodz have already been employed elsewhere. However, while some were implemented successfully, others have since come under severe criticism. Not only do the Expo fairs show the culture of the host country but also present its range and organizational efficiency. The solutions developed and presented by the Polish candidature should therefore be of the highest quality. The argument that "since their creation in the middle of the 19th century, the location of Word's Fairs has always confirmed the leadership of the host country" (Légise, Poy 2010) may of course be widely discussed but it does reflect how the topic of the exhibition and the host country itself are perceived.

The first exhibitions in London and Paris focused on the key industrialization processes in the 19th century. Today, the issue of industrial inheritance is making a comeback. Problems and challenges of post-industrial area renewal undoubtedly constitute one of the most basic challenges of modern urban areas. A historical analysis of the past Expos clearly shows that the focus of the events has shifted towards the thriving economies in the United States, and, next, towards Japan and China. It is still uncertain today whether or not Poland will become part of the tendency to focus on Europe once again. What is clear, however, is that the candidature of Lodz, located in a prospering country, is an response to one of the most basic problems of modern society. The Expo may again become a real instrument of progress, even if no great infrastructural projects are designed, as they used to be. Today, it is the slightly less spectacular operations which solve the actual needs of the local population that are the most successful. In this context, a juxtaposition of the exhibitions in Lisbon and Seville provides interesting insights. In Lisbon, just as in Lodz, the plan was to reuse $70 \%$ of the exhibition constructions. A similar idea inspired the organizers in the Andalusian city but it was "Lisbon, for its Expo '98, unlike Seville for that of 1992, [which] use[d] the occasion not to create spectacular ephemera, but to build a new district" (JFP 1998, 21).

Thanks to the meticulous strategy and implementation, Portugal had realized only buildings and constructions which later became part of the city. The Lisbon site was 
connected with the city center and airport by the underground and new roads. Residential buildings created in the exhibition site were adapted to the needs of local users after the event. This strategy as well as the project of demountable pavilions to be relocated after the fair are both employed in Lodz. The case of Expo '98 is a reminder that not all proposed spatial solutions prove useful in everyday life. In some places, the relation between the street and buildings is not balanced, which may be the result of unexploited ground floors. Nevertheless, the main idea behind the Lisbon strategy, that is to "ensure practicable buildings result after the show (the demountable one will be re-erected in a provincial city) and to avoid ending up with useless tatty pavilions à la Seville" (Davey 1997, 13) was implemented successfully. Attempts at converting the exhibition site into a science park have been made in Seville, but so far the project has not been realized (Légise, Poy 2010).

To counter the possible problems connected with organizing the Expo, a realistic assessment of the popularity of the event should be carried out. This aspect will determine many urban and economic solutions. The case of Hannover illustrates this relation well. The local university expected the Expo to create around 100.000 job positions for one year in the region (Luginsland 1994, 88). However, out of the estimated 40 million guests only 18 million arrived. The expected 'catalyst effect' of the Expo which was supposed to have dynamized the city was therefore significantly smaller. Moreover, the overestimation deepened the budget deficit of the project (Légise, Poy 2010, 179). The Expo exhibition, after all, is only a prologue, a driver of progress that helps address the challenges the territory is facing.

Lodz should internalize the experience of the Expo in Lisbon, where the buildings created for the event were later adapted to the functional needs of the city. This approach made the Expo a coherent element of the general urban development strategy, which is also recommended in the case of Lodz. On the other hand, the case of Saragossa is an example of damage to urban tissue caused by a planning process which focused solely on the immediate functional needs of the event. As the case of Hannover clearly shows, the economic influence of the planned investments should not be overestimated, but, rather, rationally assessed. A catalyst effect is certain to take place. However, it is not a temporary economic boost but sustained economic development that is the ultimate goal of hosting Expo 2022.

\section{Conclusions}

As indicated by the previous events of the kind, the exhibition has the potential to significantly advance functional, economic and social transformation of the city. However, if it is to become a coherent element of the general urban development strategy, its planning needs consistency. Poland's candidature alone will undoubtedly complement and boost projects which are already underway in Lodz and, if properly developed, will enhance their impact. Projects introduced today, such as Area Renewal Program or the 
New Center of Lodz, need to include the suppositions of the Exhibition's masterplan so that if Lodz does win the nomination, no spatial or functional conflicts will arise in the area. To that end, the planning process needs to be accompanied by wide-range public consultations with organizations engaged in all important investments in the whole city, as the exhibit is not restricted to its 25 ha area, but includes associated events in other parts of the urbanized zone. Finally, all activities and events should be considered in terms of the whole country, eg. a wider look on transportation (especially by rail) may ensure better accessibility of the city.

Revitalisation is a complex, interdisciplinary process which brings together "activities for local communities, space, and economy" (The Urban Renewal Act 2015, Art. 2. 1.). As this article illustrated, the Expo in Lodz may siginificantly faciliate in this complex process. Its influence is manifold. Specific investment activities such as rebuilding an element of the city center to boost the economy and thereby create new jobs is just one example. Strenghtening the local pride of denizens, which could translate into a greater interest among prospective visitors, is another. The lasting character of these changes is absolutely paramount: "it is desirable that the ideas and reflections developed within these powerful temporary cities continue to sprout in the city after the exterior exposition" (Zhuo 2010, 39). The International Specialized Expo should not be considered a temporary event but, rather, a process of spatial changes which are part of a holistic urban development strategy. The spatial management of the exhibit in Lodz as well as of the displayed items themselves, should embody the strategy of making use of the target urban tissue. It is the strategy that, in the long run, constitutes added value for the city and its inhabitants.

Finally, the article's argument is reasserted by the Secretary General of the BIE: "For the city, Expos are a key part of a strategic plan for urban development and act as catalysts for accelerating infrastructural transformations" (Loscertales 2010, 4). Lodz's candidature is not an empty slogan or a passive application. The city provides a sound basis for the public discussion about revitalisation. Whether Lodz will truly benefit from the Expo depends on all of us: the city's inhabitants, officials and co-organizers of the exhibition. Evidently, however, the application alone strengthens the sense of community in the city. The Expo, by promoting the topic of revitalisation and rich local post-industrial inheritance, becomes an open platform for the exchange of experiences.

\section{References}

Cysek-Pawlak M.M., 2016, Adaptacja zespołu dawnej elektrocieptowni EC1, „Renowacje i Zabytki” nr 57. Davey P., 1997, Lisbon Expo 98, “Architectural Review”, No. 1202.

Delizee P., 2000, Expo 200 à Hanovre: les concepteurs sons appréhendé le futur, "A+” No. 164.

Kulesza K., 2016, Łódź Expo 2022 - miasta na nowo, z szacunkiem dla dziedzictwa, „Renowacje i Zabytki” nr 57.

Landry Ch., 2013, Kreatywne miasto, Nowe Centrum Kultury, Warszawa.

Légise F., Poy C., 2010, What is the purpose of word's fairs?,"Architecture d'Aujoud'hui” no. 377. 
The Local Strategy of Urban Renewal in Lodz 2020+, 2015, The City Council of Lodz [Założenia Lokalnego Programu Rewitalizacji Łodzi 2020+, 2015, Urząd Miasta Łodzi].

Loscertales V.G., 2010, Advancing public diplomacy through World Expos, http://www.bie-paris.org. (dostęp 30 września 2016).

Luginsland M., 1994, Hanover: prélude à l'Expouniverselle de l'an 2000, "Urbanisme" no. 276-277.

Magnuszewska A., 2016, Expo w Nowym Centrum, „Dziennik Łódzki”, http://www.dzienniklodzki.pl (dostęp 30 września 2016).

Monclús Fraga J.F., 2006, Exposiciones internacionales y urbanismo. El proyecto Expo Zaragoza 2008, Universitat Politécnica de Cataluña, Saragossa.

National Urban Policy 2023 [Krajowa Polityka Miejska 2023. Dokument przyjęty uchwałą Rady Ministrów w dniu 20 października 2015 r. Ministerstwo Infrastruktury i Rozwoju. Departament Polityki Przestrzennej. Warszawa].

The Urban Renewal Act, 9 October 2015 (Journal of Laws, item 1777), 2015. [Ustawa z dnia 9 października 2015 r. o rewitalizacji (Dz.U. z 2015 r., poz. 1777)].

Viano M., 2006, Donner une crédibilité Au renouveau de la ville, "Le Moniteur des traveaux public et de bâtiment" no. 5333 .

Wiśniewski M., 2010, Wiązanie energii, czyli rewitalizacja dawnej elektrociepłowni EC-1 w Łodzi i jej adaptacja na cele kulturalno-artystyczne, [w:] Modele rewitalizacji i ich zastosowanie w miastach dziedzictwa europejskiego,Międzynarodowa Konferencja Pro-Revita Łódź, 2008, red. B.Walczak, Wydawnictwo Biblioteka, Łódź.

Zhuo J., 2010, Quelles suit es Au festin?, "Urbanisme” no. 375. 